BMJ Paediatrics Open

\section{Sports sponsorship and young people: good or bad for health?}

Robin Ireland, ${ }^{\oplus 1}$ Emma Boyland $^{2}$
To cite: Ireland R, Boyland E. Sports sponsorship and young people: good or bad for health? BMJ Paediatrics Open 2019;3:e000446. doi:10.1136/ bmjpo-2019-000446

Received 7 April 2019 Revised 23 May 2019 Accepted 6 June 2019
Check for updates

(c) Author(s) (or their employer(s)) 2019. Re-use permitted under CC BY-NC. No commercial re-use. See rights and permissions. Published by BMJ.

${ }^{1}$ Institute of Health and Wellbeing, School of Social and Political Sciences, University of Glasgow, Glasgow, UK ${ }^{2}$ Department of Psychological Sciences, University of Liverpool Liverpool, UK

Correspondence to Robin Ireland; research@ hegroup.org.uk
Sport has a history of seeking commercial funding to support its growing overheads, and big food and beverage corporations have been willing to oblige. For example, Coca-Cola has been associated with the Olympics since at least 1928. Sponsoring companies often claim that their sponsorship campaigns are not aimed at children and therefore should not be subject to scrutiny, but the global television (TV) audience that mega events such as the Olympics and sports like football achieve (reflecting fan bases of individuals across the lifespan) renders this argument barely credible. Because of the types of products most promoted through sport (foods and beverages high in fats, sugars and/or salt), health academics are now questioning the potential health impact of these sponsorships in professional sport. ${ }^{1}$ Even at grass roots and junior sport, one study in Australia found that 9 in 10 companies sponsoring children's sports development were promoting unhealthy food. ${ }^{2}$ The detrimental effects of unhealthy food and beverage marketing on children's diets are well documented, ${ }^{3}$ and as a result, policies have been put in place in the UK and other nations to try to restrict children's exposure to such marketing via TV and the internet. Here, we suggest that sports sponsorship by the food and drink industry warrants similar regulatory attention.

Kellogg's were long associated with swimming, a sport that traditionally receives much less income than football (whether American Football or association football), baseball or cricket. Kellogg's relationship with the English ASA (formerly the Amateur Swimming Association rebranded as Swim England in 2017) dates back to 1997. The Kellogg's logo was reproduced on millions of badges and certificates awarded to children, from those swimming their first five metres to awards for achievements across a range of strokes and aquatic sports. For example, the Kellogg's Frosties breakfast cereal (11 g sugar per $30 \mathrm{~g}$ serving) was prominently presented on materials for the 'Duckling Award', designed to 'help toddlers enjoy learning to swim'. For context, current guidance in the $\mathrm{UK}^{4}$ is that children aged between 4 and 6 years should not consume more than $19 \mathrm{~g}$ of sugar per day and children aged between 7 and 10 , no more than $24 \mathrm{~g}$.

McDonald's sponsorship of events such as the men's FIFA (Fédération Internationale de Football Association) World Cup is well known. Every player coming out onto the pitch for a match in the 2018 World Cup in Russia was accompanied by a 'player mascot'-a child wearing a McDonald's tee shirt. The 22 mascots wore a full playing strip of shirt, shorts and socks all in the striking McDonald's colours of yellow and red. The company's financial relationships with grassroots football is possibly less well known. McDonald's describes itself as the 'longest-standing supporter of grassroots football in the UK', having worked with the football association (FA), the Irish FA, Scottish FA and Football Association of Wales since 2002. The UK programme purportedly aims to provide 'fun football' experiences for children featuring Community Football Days. McDonald's use social media to promote their programme; the Grassroot Football Twitter Account (@FunFootballUK) had 11.3 K followers in March 2019.

At the beginning of the 2017/2018 football season, the English Premier League announced that Cadbury, a chocolate manufacturer owned by Mondelez, would be their 'Official Snack Partner'. Cadbury stated that they would be encouraging 'healthy and active lifestyles' through a 'Primary Stars' programme that provides educational resources for schools across England and Wales. Coca-Cola became another partner of the Premier League in January 2019. Their 31/2-year financial partnership is accompanied by a campaign called, Where Everyone Plays' which has already involved a tour around England using the Premiership brand to promote Coca-Cola's products. 
Sport sponsorship works by increasing brand awareness and driving positive consumer perceptions about a brand which, in turn, lead to brand loyalty and anticipated increases in sales. Bruce Learner, Kellogg's Corporate Social Responsibility Manager in 2009, was quoted, "I'm sure our long-standing association and active support in helping children to learn to swim has a real positive impact on consumers' perceptions of us." Sponsorship of sport has certainly had this effect in Australia where a study showed that over $80 \%$ of children aged between 10 and 14 years received a voucher or certificate from a food or beverage company to reward sport performance and that this led to many junior sports players considering food company sponsors as 'kind, generous and cool'. Associating unhealthy products with sport also creates a 'health halo' that these items rarely deserve. This can make it difficult for children, or indeed parents, to identify the genuinely healthier choices.

Clearly it suits Kellogg's, Coca-Cola, Cadbury (Mondelez) and McDonald's interests to be seen as good corporate citizens contributing to our better health by encouraging physical activity. While not all their products may be considered unhealthy, these companies' directors would prefer a conversation about physical activity than about the contribution of their products to the global burden of non-communicable diseases such as type 2 diabetes and obesity. Coca-Cola even admitted that they want to "change the conversation about obesity" so that attention is deflected away from diets high in ultra-processed foods and sugary drinks being the principal cause of overweight to a greater focus on physical inactivity as the leading factor. For each of the 'partnerships' described above, the industry sponsor emphasises how the financial contribution provided by the corporate giants promotes participation in sport. Kellogg's uses similar language around encouraging healthier lifestyles to promote other brands targeting children. Kellogg's supports \#GiveAChildABreakfast. And who wouldn't? But they go on to promote brands such as Coco Pops to schoolchildren; a cereal containing $35 \%$ sugar. What message is this giving young children about dietary and physical health?

It is only comparatively recently that sport sponsorship by the tobacco industry was curtailed after a long and lucrative relationship with motor racing, tennis and snooker among others. This followed the WHO's Framework Convention on Tobacco Control which included an article banning tobacco advertising, promotion and sponsorship, including through sport, on the premise that promotion of tobacco brands has clear health implications. The conversation is not there yet with sports, and the food and beverage industry.

Sports fans, football fans in particular, may not be concerned about where their club's income comes from as long as they are successful but governments have a duty to protect the health of their citizens. Corporate sponsorship is also raising concern in the arts world; for example, campaigners have protested against BP's sponsorship of British Museum because of concerns about climate change and BP's role in the Iraq war. Amnesty International used the term 'sportswashing' in their description of how they believed Manchester City's Abu Dhabi owners were trying to improve the image of the United Arab Emirates through their huge investment in the Premiership club.

Sport's acceptance of sponsorship from food and beverage companies contributes to the obesogenic environment our children are being raised in which has driven growing levels of obesity among children both in North America and Europe but now across the globe. We would encourage further research into these relationships and their potential negative cost to society. It is time for sport's governing bodies and clubs to consider an ethical code for their future financial partnerships with Big Food, and for governments to consider stricter regulation of this activity, to demonstrate a true commitment to the health of our children.'

Contributors RI wrote the first manuscript draft. EB provided input and made revisions. Both authors approved the final manuscript version and responded to reviewers' comments.

Funding The authors have not declared a specific grant for this research from any funding agency in the public, commercial or not-for-profit sectors.

Competing interests None declared.

Patient consent for publication Not required.

Provenance and peer review Commissioned; externally peer reviewed.

Open access This is an open access article distributed in accordance with the Creative Commons Attribution Non Commercial (CC BY-NC 4.0) license, which permits others to distribute, remix, adapt, build upon this work non-commercially, and license their derivative works on different terms, provided the original work is properly cited, appropriate credit is given, any changes made indicated, and the use is non-commercial. See: http://creativecommons.org/licenses/by-nc/4.0/.

\section{REFERENCES}

1. Ireland R, Bunn C, Reith G, et al. Commercial determinants of health: advertising of alcohol and unhealthy foods during sporting events. Bull World Health Organ 2019;97:290-5.

2. Woolloomooloo: Cancer Council NSW. Building solutions to protect children from unhealthy food and drink sport sponsorship. Available: http://cancercouncil.com.au/wp-content/uploads/2011/ 12/CCN13208-Sports-sponsorship-report-0212-FA_WEB.pdf?_ga= 2.121337416.1175617265.1549904685-1593370296.1549904685 [Accessed 16 Feb 2019].

3. Cairns G, Angus K, Hastings G, et al. Systematic reviews of the evidence on the nature, extent and effects of food marketing to children. A retrospective summary. Appetite 2013;62:209-15.

4. Scientific Advisory Committee on Nutrition. Carbohydrates and Health. Norwich: TSO, 2015. Available: https://assets.publishing. service.gov.uk/government/uploads/system/uploads/attachment data/file/445503/SACN_Carbohydrates_and_Health.pdf

5. swimming.org. Swimming Helps Kellogg's Achieve A Top 5 Brand Trust Position. Available: https://www.swimming.org/about-us/ swimming-kelloggs/swimming-helps-kelloggs/4478/ [Accessed 16 Feb 2019].

6. Kelly B, Baur LA, Bauman AE, et al. "Food company sponsors are kind, generous and cool": (Mis)conceptions of junior sports players. Int J Behav Nutr Phys Act 2011;8.

7. Barlow P, Serôdio P, Ruskin G, et al. Science organisations and Coca-Cola's 'war' with the public health community: insights from an internal industry document. J Epidemiol Community Health 2018;72:761-3. 